\title{
EFFICIENCY OF SOME BIO-INSECTICIDES AGAINST FIELD AND LABORATORY INDIVIDUALS OF CULEX PIPIENS (L.) (DIPTERA: CULICIDAE)
}

\author{
Mawaddh A. El-Hussiny ${ }^{1 *}$, Samia A. Hassan ${ }^{1}$; M.F. Mahmoud ${ }^{2}$ \\ and Ali A. El-Sebae ${ }^{1}$
}

1. Dept. Environ. Porte., Fac. Environ. Agric. Sci., Arish Univ., Egypt.

2. Dept. Plant Prot., Fac. Agric., Suez Canal Univ., Egypt.

\begin{abstract}
Culex pipiens (L.) (Diptera: Culicidae) is the most important medical insect in many parts of the world. Biological and natural chemicals have many advantages over the traditional ones in case of mosquito control. Radiant, Isomectin and Nimbecidine insecticides were evaluated for their efficiency against the wild and laboratory individuals of late $3^{\text {rd }}$ instar larvae of Culex pipiens at different concentrations and two periods of exposure under laboratory conditions. Results revealed that the mortality percentage was increased gradually with increasing the insecticide concentrations and the mortality percentage showed significant differences between concentrations and control. Moreover, results showed that mortality percentage increased with increasing the period of insecticide exposure. Tolerance and lab strain of Culex pipiens to insecticides showed that wild individuals were more tolerant than lab individuals to Radiant and Isomectin, and vice versa with Nimbecidine. Results revealed also that Radiant insecticide was the most effective insecticide against late $3^{\text {rd }}$ instar larvae of Culex pipiens followed descendingly by Isomectin and Nimbecidine for both wild and lab strains of mosquitoes. Moreover, the toxicity index of the tested insecticides proved the high toxicity of Radiant than Isomectin and Nimbecidine. Toxicity index of Radiant at $\mathrm{LC}_{50}$ showed such superior efficacy $(100 \%)$ followed by Isomectin and Nimbecidine.
\end{abstract}

Key words: Culex pipiens, bio-insecticides, toxicity, tolerance.

\section{INTRODUCTION}

In Egypt, the mosquito Culex pipiens is the main vector of filariasis and some arboviruses such as Rift Valley Fever and West Nile Fever viruses (Southgate, 1979; Hanafi et al., 2011). Cx. pipiens, therefore, is the main target in control programs against these diseases. Culex pipiens larvae breed in different kinds of water bodies such as wet pit latrines, septic tanks, cesspits, cesspools, drains and canals containing stagnant water polluted with organic waste. They also breed in polluted water associated with home industries, for example coconut husk pits. Other breeding sites are pools and unused wells used for dumping garbage (Zayed et al, 2006).

For many decades, the scientists have been engaged in searching the effective and efficient of the mosquito control program based on chemicals. The resistance to conventional insecticides is the major problem in mosquito control program. The traditional insecticides are environmentally non-sustainable and harmful the natural enemies, consequently may due to disturbance in the natural balance and most

\footnotetext{
* Corresponding author: Tel.: +201090849079
}

E-mail address: mawdah.elhussiny@gmail.com 
mosquito species are becoming physiologically resistant (Karunamoorthi and Sabesan, 2013).

The appearance of such problems has been accompanied by growing interest to use new safe bio insecticide with a new mode of action specially when dealing with water (Salgado, 1997; Salgado, 1998). Spinosad is a secondary metabolite of the aerobic fermentation of the naturally occurring soil actinomycete Saccharopolyspora spinose which produces a mix of compounds known as spinosyns A and D (Athanassiou et al., 2008).

Neem contains several active ingredients; such as Azadirachtin, Salanin, Meliantriol, Nimbecidine and Nimbin, which are the most known and significant components. They act in different ways under different circumstances (Saxena, 1983; Ventura and Ito, 2000; Damaria, et al., 2004 Mahmoud and shoeib 2008; Shoieb et al 2010). Extracts of neem are effective mosquito larvicides and inhibit metamorphosis (Saxena, 1983).

Azadirachtin, a complex tetranortriter penoid limonoid from the neem seeds, is the main component responsible for the toxic effects in insectzs. Neem insecticides are efficient mainly in a variety of different ways: as an antifeedant, insect growth regulator and sterilant.

Isomectin is a semi-synthetic derivative of the compound avermectin, which is a natural fermentation product of the soil bacterium Streptomyces avermectinius (Burg et al., 1979; Campbell, 2012). The Isomectin family of endectocides are 16membered macrocyclic lactones each of which is comprised of a dissacharide, benzofuran and spiroketal moieties. The family also includes eprinomectin, abamectin, selamectin, doramectin and enamectin, though ivermectin has been shown to have the strongest nematocidal and insecticidal properties (Pitterna et al., 2009; Butters et al., 2012; Campbell, 2012).

The first study on the effects of Avermectin on mosquito disease vectors proved that Avermectin reduced the survivorship of An. stephensi, A. aegypti, $C x$. pipiens and $C$. quinquefasciatus (Pampiglione et al., 1985).

The objective of the present investigation is: to evaluate the efficiency of some natural bio-insecticides against wild and lab strain of Culex pipiens larvae.

\section{MATERIALS AND METHODS}

\section{Rearing of lab strain of Culex pipiens}

Culex pipiens larvae were brought from Research Institute of Medical Entomology in Cairo, Egypt, the rearing was conducted in Entomology Lab., Plant Protection Department, Faculty of Agriculture, Suez Canal University. They reared under constant conditions of $27 \pm 2^{\circ} \mathrm{C}$ and relative humidity $60 \pm 10 \%$.

The larvae were kept in a plastic containers $(14 \times 20) \mathrm{cm}$, and sprinkled with bread crumbs twice a day on water surface. Pupae were pipette, placed in groups into plastic container half filled with clean water and transferred to emerging adult cages (25 $\times 25 \times 25 \mathrm{~cm}$ ) with wire screen.

Emerged adults were provided with a piece of cotton that was socked in $10 \%$ sugar solution, blood meals were allowed for female adults every 48 hours because it's necessary for eggs maturity. The mass of eggs was moved in the plastic containers until hatching.

\section{Bio-Insecticides}

1. Spinosad (Radiant): (active ingredient: Spinetoram 12\%) Spinetoram is a new member of Spinosad, Spinosad consists of spinosyn A and D (Su, 2014), Molecular formula: $\mathrm{C}_{42} \mathrm{H}_{69} \mathrm{NO}_{10}$. 
2. Nimbecidine: (active ingredient: Neem oil $75.5 \%$, Azadirachtin (neem butter) $3.5 \%$, Emulsifier 10\%, Stabilizers $2 \%$ and Diluent 9\%), Azadirachtin Molecular formula: $\mathrm{C}_{35} \mathrm{H}_{44} \mathrm{O}_{16}$.

3. Isomectin: (active ingredient: Abamactin $1.8 \%$ ), Abamectin consists of avermectin $\mathrm{B}_{1 \mathrm{a}}$ and avermectin $\mathrm{B}_{1 \mathrm{~b}}$, Molecular formula: $\mathrm{C}_{48} \mathrm{H}_{72} \mathrm{O}_{14}$.

\section{Bioassays}

Batches of 10 of late $3^{\text {rd }}$ instar larvae were put in glass breakers, the glass breakers filled with $100 \mathrm{ml}$ of dechlorinated water - by lefting tap water for $24 \mathrm{hrs}$ - containing different concentrations of three natural bio-pesticides; Radiant, Nimbecidine and Isomectin. The insecticides concentrations were tested against late $3^{\text {rd }}$ instar. Five replicates were used for each concentrations as well as for the control. Each breaker was inspected 24 and 48 hours post treatment and mortality were recorded.

The experiment was repeated twice in different time for both lab strain and filed strain under lab condition of controlled temp $(27 \pm 2) \quad{ }^{\circ} \mathrm{C}$ and relative humidity $(60 \pm 10) \%$, spectic tank water was used in filed strain bioassays, and no food supply for tested larvae during the bioassays.

\section{Statistical Analysis}

Mortality rates for each insecticide were analyzed through ANOVA (SAS Institute, 2004). If there were significant differences $(\mathrm{P} \leq 0.05)$, differences were compared using FLSD test.

A standard probit analysis was used to calculate $\mathrm{LC}_{20}, \mathrm{LC}_{50}, \mathrm{LC}_{90}$ and slope of the tested insecticide using "probit" analysis program of Schoofs and Willhite (1984). Resistance ratio $(\mathrm{RR})=\mathrm{LC}_{50}$ of the wild strain/ $\mathrm{LC}_{50}$ of the lab strain.

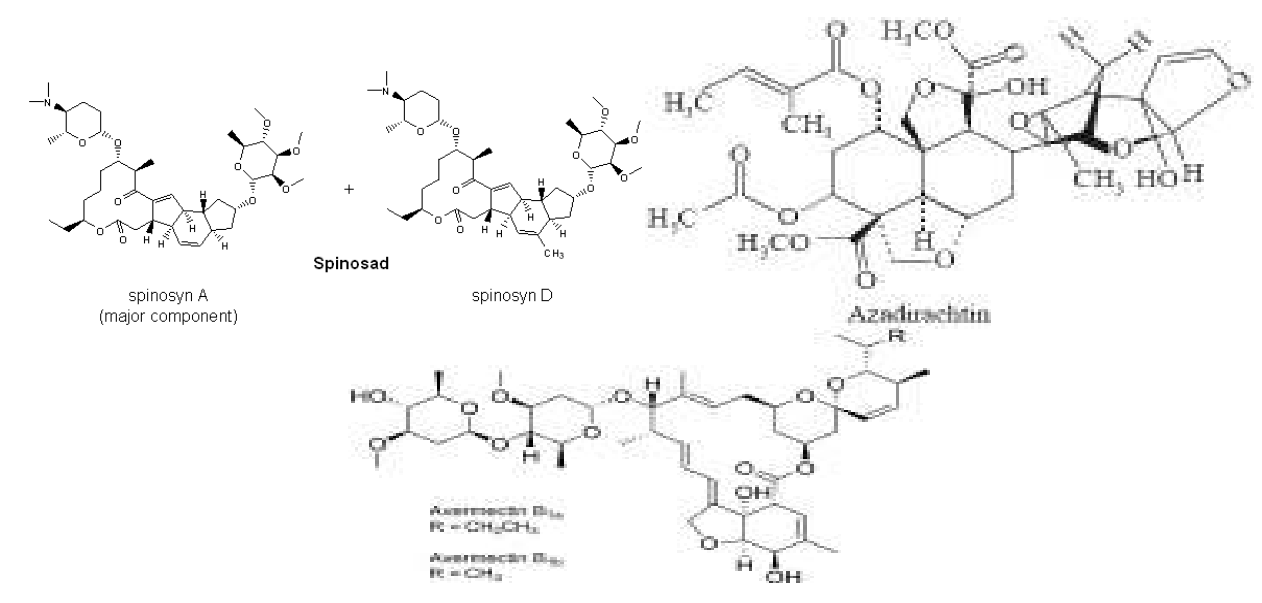

Table (1). Names and concentrations of the tested bio-pesticides.

\begin{tabular}{lccccc}
\hline \multicolumn{1}{c}{ Bio-pesticide } & \multicolumn{5}{c}{ Concentration (mg/l) } \\
\hline Radiant (wild and lab strains) & 1 & 0.1 & 0.01 & 0.001 & 0.0001 \\
Nimbecidine (wild and lab strains) & 100 & 10 & 1 & 0.1 & 0.01 \\
Isomectin (wild strain) & 100 & 10 & 1 & 0.1 & 0.01 \\
Isomectin (lab strain) & 10 & 1 & 0.1 & 0.01 & 0.001 \\
\hline
\end{tabular}




\section{RESULTS}

Results in Table 2 indicate that the mortality percentage of wild strain of Culex pipiens larvae after 24 and 48 hours of exposure to different concentrations of Radiant insecticide. The obtained results revealed that the mortality percentage was increased gradually with increasing the Radiant concentrations and the mortality percentage showed significant differences between concentrations and control $(\mathrm{F}=143.218 ; \mathrm{P} \leq 0.0000$ after $24 \mathrm{hr}$., of treatment and $\mathrm{F}=97.88 ; \mathrm{P} \leq 0.0000$ after 48 $\mathrm{hr}$., of treatment).Moreover, results showed that mortality percentage increased with increasing the time of insecticide exposure for Culex pipiens larvae.

Also, the toxicity lines in Fig. 1 revealed that the regression equation and regression of the mortality percentage after 24 and 48 hours of exposure $\left(y=-23.2 x=128.5 ; R^{2}=\right.$ 0.939 after $24 \mathrm{hr}$., of treatment and $\mathrm{y}=-$ $23.62 \mathrm{x}=141.8 ; \mathrm{R}^{2}=0.872$ after $24 \& 48 \mathrm{hr}$., of treatment. results revealed that the elevation mortality rates were concentration-dependent and time of exposure.

Results obtained from Table (3) show that the mortality percentage of the late $3^{\text {rd }}$ instar of lab strain of Culex pipiens larvae after 24 and 48 hours of exposure to different concentrations of Radiant as bioinsecticide.

Results revealed that the mortality percentage was increased gradually with increasing the Radiant concentrations and the mortality percentage showed significant differences between concentrations and control $(\mathrm{F}=295.646 ; \mathrm{P} \leq 0.0000$ after $24 \mathrm{hr}$., of treatment and $\mathrm{F}=176.110 ; \mathrm{P} \leq 0.0000$ after $48 \mathrm{hr}$., of treatment).

In addition to, results showed that mortality percentage increased with increasing the time of insecticide exposure for Culex pipiens larvae. Also, the toxicity lines in Fig. 2) revealed that the regression equation and regression of the mortality percentage after 24 and 48 hours of exposure $\left(y=-24.2 x=134.6 ; R^{2}=0.917\right.$ after $24 \mathrm{hr}$., of treatment and $\mathrm{y}=$ $21.02 x=137.6 ; R^{2}=0.909$. results revealed that the elevation mortality rates were concentration-dependent and time of exposure.

Results in Table 4 show a great decrease in the $\mathrm{LC}_{20}, \mathrm{LC}_{50}$ and $\mathrm{LC}_{90}$ values by increasing times of exposure, i.e: the $\mathrm{LC}_{90}$ value after 48 hours had nearly (1/6) the value after 24 hours of exposure in the wild strain. The $\mathrm{LC}_{50}$ value after 48 hours is 11.5 time decrease than the value of $\mathrm{LC}_{50}$ after 24 hours of exposure in the lab strain. Also the value of $\mathrm{LC}_{50}$ after 48 hours is about 12 times decrease than the value of $\mathrm{LC}_{50}$ after 24 hours of exposure in the wild strain. In addition, the value of $\mathrm{LC}_{90}$ after 48 hours had nearly (1/3) the value of $\mathrm{LC}_{90}$ after 24 hours of exposure in the lab strain.

The slope values either in wild or in lab strain proved that the homogeneity between wild and lab individuals. The resistance ratio of the response of the late $3^{\text {rd }}$ instar larvae of Culex pipiens to the bioinsecticidal pressure of Radiant was 1.71 and 1.66 after 24 and $48 \mathrm{hr}$., of exposure in the wild strain.

Results obtained from Table (5) show that the mortality percentage of the late $3^{\text {rd }}$ instar of wild strain of Culex pipiens larvae after 24 and 48 hours of exposure to different concentrations of Nimbecidine insecticide.

Results revealed that the mortality percentage was increased gradually with increasing concentrations of Nimbecidine and the mortality percentage showed significant differences between concentrations and control $(\mathrm{F}=92.608 ; \mathrm{P} \leq$ 0.0000 after $24 \mathrm{hr}$., of treatment and $\mathrm{F}=55.059 ; \mathrm{P} \leq 0.0000$ after $48 \mathrm{hr}$, of treatment). 
SINAI Journal of Applied Sciences (ISSN: 2314-6079) Vol. (6) Is. (3), Dec. 2017

Table (2). Effect of different concentrations of Radiant on larvae of wild strain of Culex pipiens after 24 and 48 hours exposure.

\begin{tabular}{ccc}
\hline $\begin{array}{c}\text { Concentration } \\
(\mathbf{m g} / \mathbf{L})\end{array}$ & \multicolumn{2}{c}{ Mortality (\%) } \\
\cline { 2 - 3 } $\mathbf{1}$ & After 24 hr., & After $\mathbf{4 8} \mathbf{~ h r} .$, \\
\hline $\mathbf{0 . 1}$ & $100 \mathrm{a}$ & $100 \mathrm{a}$ \\
$\mathbf{0 . 0 1}$ & $98 \mathrm{a}$ & $100 \mathrm{a}$ \\
$\mathbf{0 . 0 0 1}$ & $52 \mathrm{~b}$ & $94 \mathrm{~b}$ \\
$\mathbf{0 . 0 0 0 1}$ & $34 \mathrm{c}$ & $58 \mathrm{~b}$ \\
cotrol & $0 \mathrm{~d}$ & $3 \mathrm{c}$ \\
\end{tabular}

Means followed wit the same letter (column wise) are not significantly different (Tukeys HSD, P $\leq 0.05$ ).

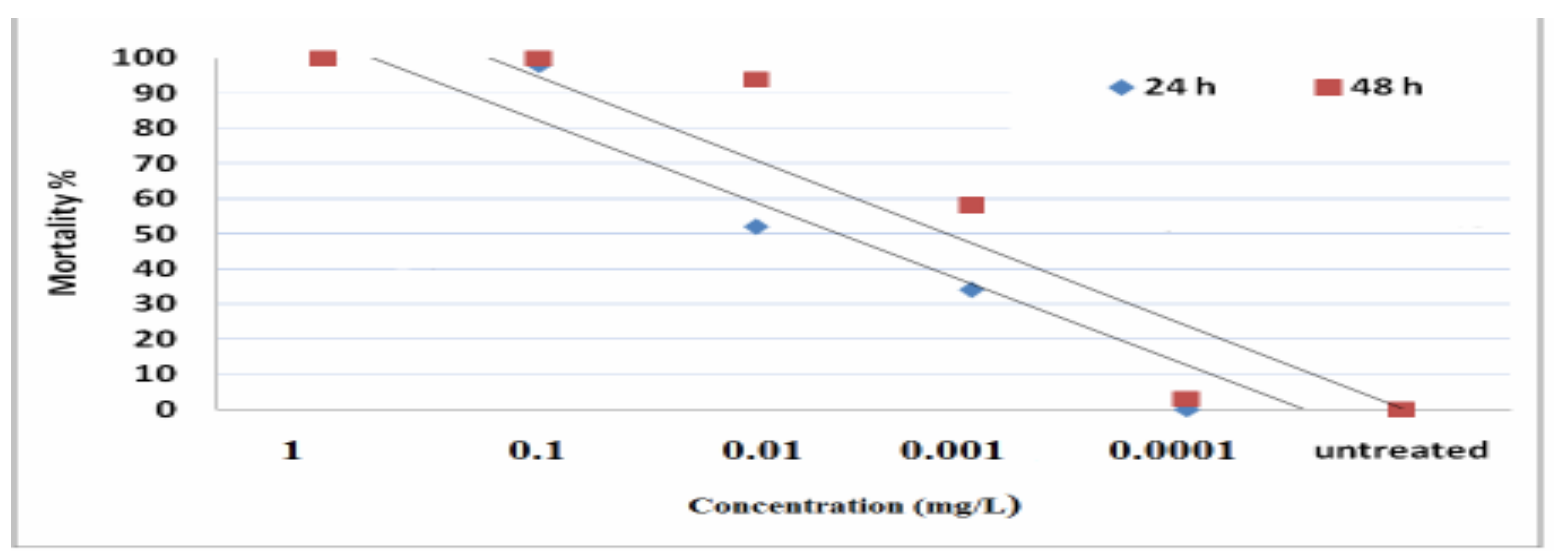

Fig. 1. Toxicity lines of Radiant against the late $3^{\text {rd }}$ instar of wild strain of Culex pipiens larvae.

Table (3). Effect of different concentrations of Radiant on the late $3^{\text {rd }}$ instar of laboratory strain of Culex pipiens larvae.

\begin{tabular}{ccc}
\hline $\begin{array}{c}\text { Concentration } \\
(\mathbf{m g} / \mathbf{L})\end{array}$ & \multicolumn{2}{c}{ Mortality (\%) } \\
\cline { 2 - 3 } & After 24 hr., & After $\mathbf{4 8 ~ h r .}$ \\
\hline $\mathbf{1}$ & $100 \mathrm{a}$ & $100 \mathrm{a}$ \\
$\mathbf{0 . 1}$ & $100 \mathrm{a}$ & $100 \mathrm{a}$ \\
$\mathbf{0 . 0 1}$ & $74 \mathrm{~b}$ & $92 \mathrm{~b}$ \\
$\mathbf{0 . 0 0 1}$ & $24 \mathrm{c}$ & $64 \mathrm{c}$ \\
$\mathbf{0 . 0 0 0 1}$ & $0 \mathrm{~d}$ & $32 \mathrm{~d}$ \\
control & $0 \mathrm{~d}$ & $0 \mathrm{e}$ \\
\hline
\end{tabular}

Means followed with the same letters (column wise) are not significantly different (Tukeys HSD, $\mathrm{P} \leq 0.05$ ). 


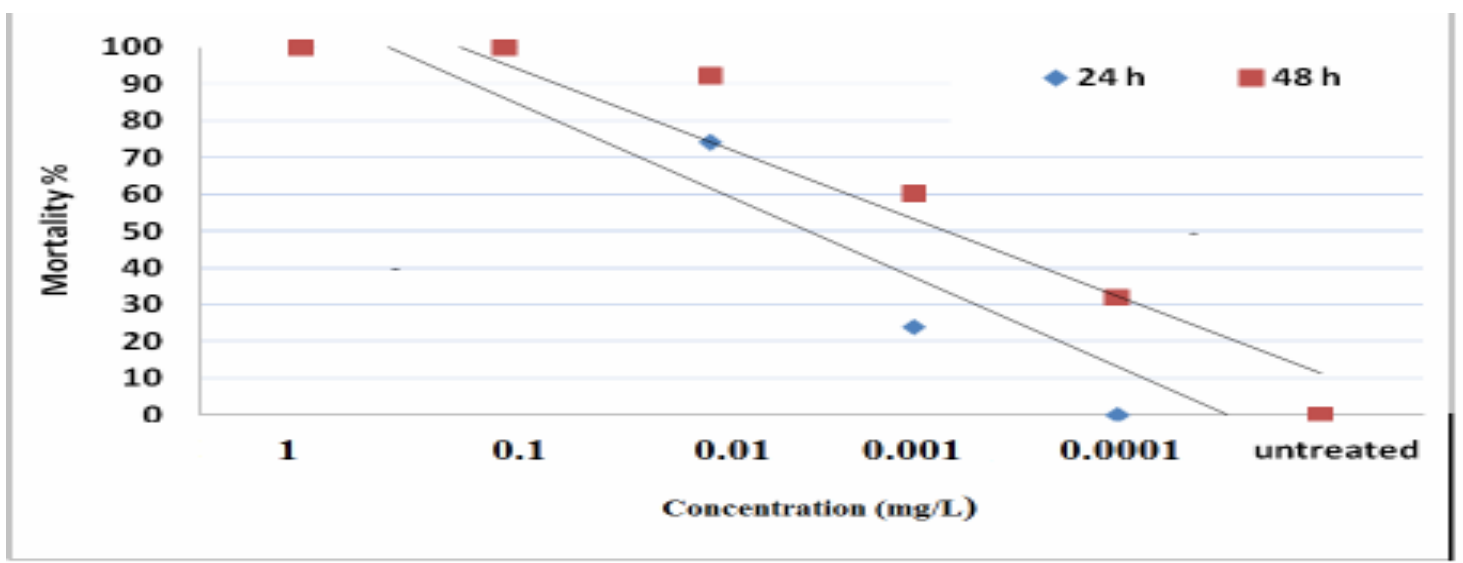

Fig. 2. Toxicity lines of Radiant against the late $3^{\text {rd }}$ instar of lab strain of Culex pipiens larvae.

Table (4). Toxicity data of Radiant against the late $3^{\text {rd }}$ instar of wild and laboratory strain of Culex pipiens larvae.

\begin{tabular}{|c|c|c|c|c|c|c|c|}
\hline $\begin{array}{l}\text { Mosquito } \\
\text { strain }\end{array}$ & $\begin{array}{c}\text { Time of } \\
\text { exposure } \\
\text { (Hours) }\end{array}$ & $\begin{array}{c}\mathrm{LC}_{20}(\mathrm{mg} / \mathrm{l}) \\
{[95 \% \mathrm{CI}]}\end{array}$ & $\begin{array}{c}\mathrm{LC}_{50}(\mathrm{mg} / \mathrm{l}) \\
{[95 \% \mathrm{CI}]}\end{array}$ & $\begin{array}{c}\mathbf{L C}_{90}(\mathrm{mg} / \mathrm{l}) \\
{[95 \% \mathrm{CI}]}\end{array}$ & Slope & $\begin{array}{c}\text { Slope } \\
\text { function } \\
\text { (S) }\end{array}$ & $\begin{array}{c}\text { Resistance } \\
\text { ratio } \\
\text { (RR) LC } \\
\text { (R0 }\end{array}$ \\
\hline \multirow[b]{2}{*}{ Wild } & 24 & $\begin{array}{c}0.001 \\
(0.001-0.001)\end{array}$ & $\begin{array}{c}0.006 \\
(0.002-0.008)\end{array}$ & $\begin{array}{c}0.097 \\
(0.075-0.155)\end{array}$ & 1.0617 & 8.630 & \multirow[b]{2}{*}{1.71} \\
\hline & 48 & $\begin{array}{c}0 \\
(0.000-0.001)\end{array}$ & $\begin{array}{c}0.0005 \\
(0.0003- \\
0.0007)\end{array}$ & $\begin{array}{c}0.0154 \\
(0.009-0.030)\end{array}$ & 0.8409 & 15.189 & \\
\hline \multirow{2}{*}{ Lab. } & 24 & $\begin{array}{c}0.0008 \\
(0.0005- \\
0.0012)\end{array}$ & $\begin{array}{c}0.0035 \\
(0.0024- \\
0.0044)\end{array}$ & $\begin{array}{c}0.0309 \\
(0.014-0.0436)\end{array}$ & 1.3471 & 5.459 & \multirow{2}{*}{1.66} \\
\hline & 48 & $\begin{array}{c}0 \\
(0.000-0001)\end{array}$ & $\begin{array}{c}0.0003 \\
(0.0002- \\
0.0005)\end{array}$ & $\begin{array}{c}0.0107 \\
(0.0063- \\
0.0216)\end{array}$ & 0.8449 & 14.760 & \\
\hline
\end{tabular}

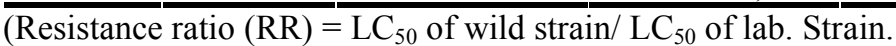

Table 5. Effect of different concentrations of Nimbecidine against the late $3^{\text {rd }}$ instar of wild strain of Culex pipiens larvae.

\begin{tabular}{|c|c|c|}
\hline \multirow{2}{*}{$\begin{array}{c}\text { Concentration } \\
(\mathrm{mg} / \mathrm{L})\end{array}$} & \multicolumn{2}{|c|}{ Mortality (\%) } \\
\hline & After 24 hr., & After 48 hr., \\
\hline 100 & $80 \mathrm{a}$ & $93 \mathrm{a}$ \\
\hline 10 & $34 \mathrm{~b}$ & $71 \mathrm{~b}$ \\
\hline 1 & $14 \mathrm{c}$ & $32 \mathrm{c}$ \\
\hline 0.1 & $13 \mathrm{~cd}$ & $31 \mathrm{c}$ \\
\hline 0.01 & $8 \mathrm{~cd}$ & $21 \mathrm{~cd}$ \\
\hline Control & $1 \mathrm{~d}$ & $7 \mathrm{~d}$ \\
\hline
\end{tabular}

Means followed with the same letters (column wise) are not significantly different (Tukeys HSD, $\mathrm{P} \leq 0.05$ ). 
Moreover, results showed that mortality percentage increased with increasing the time of insecticide exposure for Culex pipiens larvae. The toxicity lines in (Fig. 3) revealed that the regression equation and regression of the mortality percentage after 24 and 48 hours of exposure $(\mathrm{y}=$ $13.5 \mathrm{x}+72.4 ; \mathrm{R}^{2}=0.757$ after $24 \mathrm{hr}$., of treatment and $y=-16.6 x+100.6 ; R^{2}=0.905$ after $48 \mathrm{hr}$., of exposure. results revealed that mortality percentage was concentration-dependent and time of exposure.

Results obtained from (Table 6) showed that the mortality percentage of the late $3^{\text {rd }}$ instar of lab. strain of Culex pipiens larvae after 24 and 48 hours of exposure to different concentrations of Nimbecidine insecticide. Likewise the wild strain, the mortality percentage was increased gradually with increasing concentrations of Nimbecidine and the mortality percentage showed significant differences between concentrations and control $(\mathrm{F}=15.697 ; \mathrm{P} \leq$ 0.0000 after $24 \mathrm{hr}$., of treatment and $\mathrm{F}=21.543 ; \mathrm{P} \leq 0.0000$ after 48 of treatment). Moreover, results showed that, mortality percentage increased with increasing the time of insecticide exposure for Culex pipiens larvae.

The toxicity lines in Fig. 4 reveale that the regression equation and regression of the mortality percentage after 24 and 48 hours of exposure $\left(y=-16.17 x+104.6 ; R^{2}=\right.$ 0.964 after $24 \mathrm{hr}$., of treatment and $\mathrm{y}=$ $16.82 \mathrm{x}+117.7 ; \mathrm{R}^{2}=0.891$ after $48 \mathrm{hr}$., of exposure. results revealed that mortality percentage was concentration-dependent and time of exposure.

The value of $\mathrm{LC}_{20}, \mathrm{LC}_{50}$ and $\mathrm{LC}_{90}$ were tabulated in Table 7 with the corresponding slope, slope function and resistance ratio for Nimbecidine insecticide against the wild and lab strain of Culex pipiens larvae after 24 and 48 hours of exposure.
The results of larvae showed that Nimbecidine was less toxic to both of wild and lab strain of larvae. The respective values of $\mathrm{LC}_{20}, \mathrm{LC}_{50}$ and $\mathrm{LC}_{90}$ were 0.569 , 17.078 and $3000.33(\mathrm{mg} / \mathrm{l})$ after 24 hours of wild strain exposure, 0.027, 0.993 and $224.01(\mathrm{mg} / \mathrm{l})$ after 48 hours of wild strain exposure, respectively. Also, the respective values of $\mathrm{LC}_{20}, \mathrm{LC}_{50}$ and $\mathrm{LC}_{90}$ were 0.002 , 0.250 and $475.94(\mathrm{mg} / \mathrm{l})$ after 24 hours of wild strain exposure, $0.0001,0.017$ and $71.78(\mathrm{mg} / \mathrm{l})$ after 48 hours of wild strain exposure, respectively.

The resistance ratio of the response of the late $3^{\text {rd }}$ instar of Culex pipiens larvae to the bio-insecticidal pressure of Nimbecidine was 68.28 and 48.41 after 24 and $48 \mathrm{hr}$., of exposure in the wild strain; results showed relatively low level of resistance. The slope values proved that the homogeneity between lab and wild individuals.

Results in Table 8 showed that the mortality percentage of the late $3^{\text {rd }}$ instar of wild strain of Culex pipiens larvae after 24 and 48 hours of exposure to different concentrations of Isomectin insecticide. The mortality percentage showed significant differences between concentrations and control $(\mathrm{F}=213.271 ; \mathrm{P} \leq 0.0000$ after $24 \mathrm{hr}$., of treatment and $\mathrm{F}=120.092 ; \mathrm{P} \leq 0.0000$ after $48 \mathrm{hr}$., of treatment). Moreover, results showed that mortality percentage increased with increasing the time of insecticide exposure for Culex pipiens larvae.

The toxicity lines in Fig. 5 reveale that the regression equation and regression of the mortality percentage after 24 and 48 hours of exposure $\left(\mathrm{y}=-21.94 \mathrm{x}+123.4 ; \mathrm{R}^{2}=\right.$ 0.956 after $24 \mathrm{hr}$, of treatment and $\mathrm{y}=-$ $19.97 \mathrm{x}+136.7 ; \mathrm{R}^{2}=0.875$ after $48 \mathrm{hr}$., of treatment. results revealed that mortality percentage was concentration-dependent and time of exposure. 


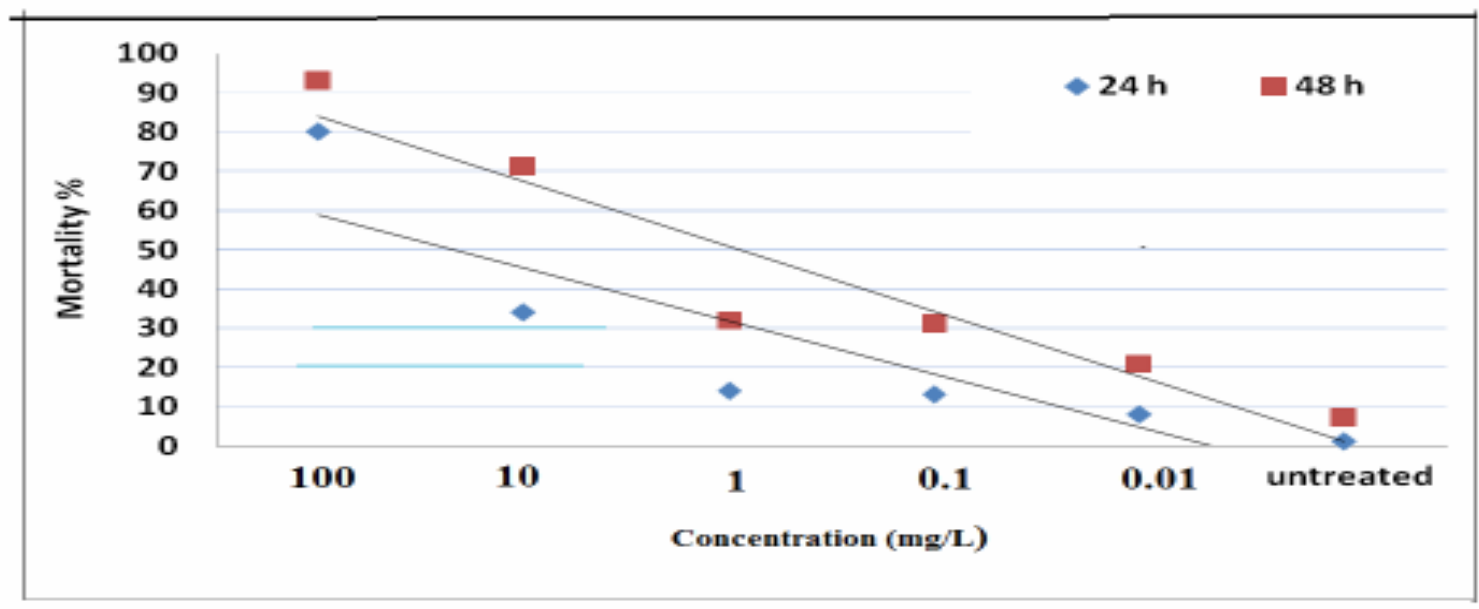

Fig. 3. Toxicity lines of Nimbecidine against the late $3^{\text {rd }}$ instar of wild strain of Culex pipiens larvae.

Table (6). Effect of different concentrations of Nimbecidine on the late $3^{\text {rd }}$ instar of lab. strain of Culex pipiens larvae.

\begin{tabular}{ccc}
\hline Concentration & \multicolumn{2}{c}{ Mortality (\%) } \\
\cline { 2 - 3 }$(\mathbf{m g} / \mathbf{L})$ & After $\mathbf{2 4} \mathbf{h r} .$, & After $\mathbf{4 8} \mathbf{~ h r} .$, \\
\hline $\mathbf{1 0 0}$ & $86 \mathrm{a}$ & $96 \mathrm{a}$ \\
$\mathbf{1 0}$ & $71 \mathrm{ab}$ & $80 \mathrm{ab}$ \\
$\mathbf{1}$ & $60 \mathrm{abc}$ & $71 \mathrm{abc}$ \\
$\mathbf{0 . 1}$ & $38 \mathrm{bc}$ & $58 \mathrm{bc}$ \\
$\mathbf{0 . 0 1}$ & $33 \mathrm{~cd}$ & $48 \mathrm{c}$ \\
Control & $0 \mathrm{~d}$ & $0 \quad \mathrm{D}$ \\
\hline
\end{tabular}

Means followed with the same letters (column wise) are not significantly different (Tukeys HSD, $\mathrm{P} \leq 0.05$ ).

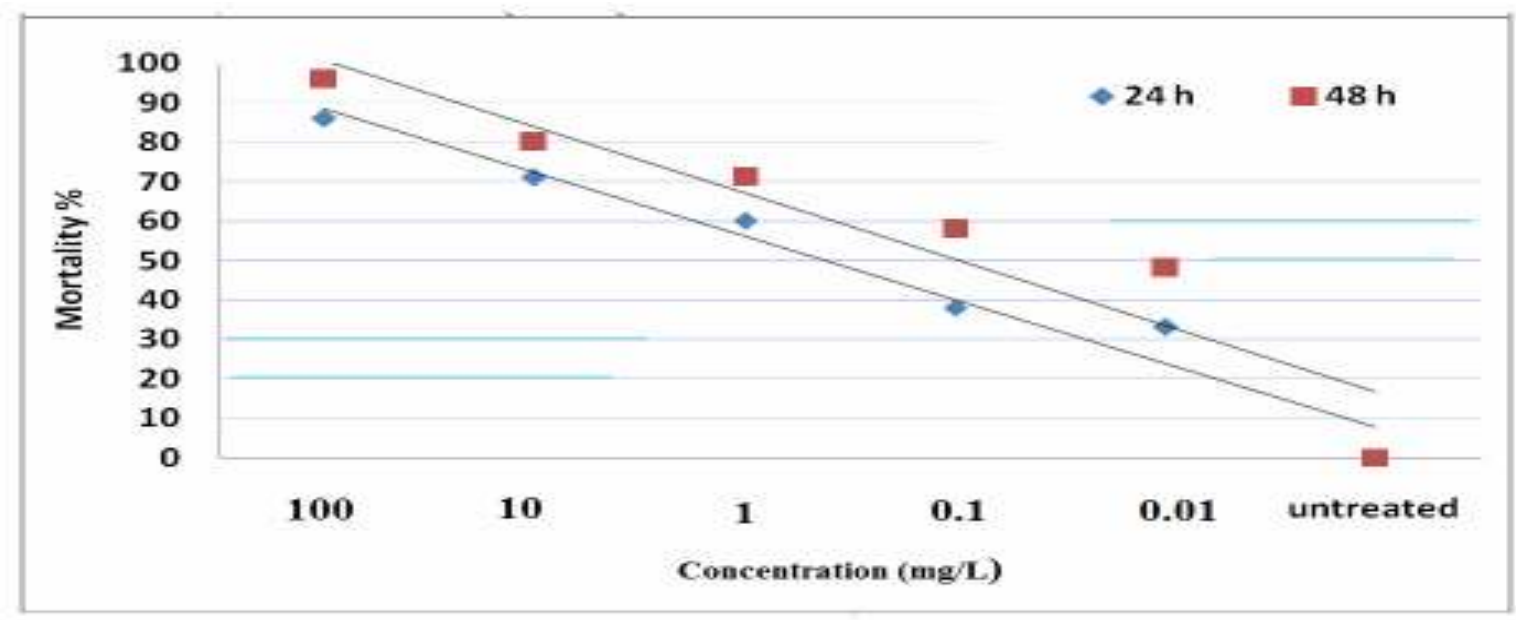

Fig. 4. Toxicity lines of Nimbecidine against the late $3^{\text {rd }}$ instar of lab. strain of Culex pipiens larvae. 
SINAI Journal of Applied Sciences (ISSN: 2314-6079) Vol. (6) Is. (3), Dec. 2017

Table (7). Toxicity data of Nimbecidine against the late $3^{\text {rd }}$ instar of wild and laboratory strain of Culex pipiens larvae.

\begin{tabular}{|c|c|c|c|c|c|c|c|}
\hline $\begin{array}{l}\text { Mosquito } \\
\text { strain }\end{array}$ & $\begin{array}{c}\text { Time of } \\
\text { exposure } \\
\text { (hour) }\end{array}$ & $\begin{array}{c}\mathrm{LC}_{20}((\mathrm{mg} / \mathrm{l})) \\
{[95 \% \mathrm{CI}]}\end{array}$ & $\begin{array}{c}\mathrm{LC}_{50}(\mathrm{mg} / \mathrm{l}) \\
{[95 \% \mathrm{CI}]}\end{array}$ & $\begin{array}{c}\mathrm{LC}_{90}(\mathrm{mg} / \mathrm{l}) \\
{[95 \% \mathrm{CI}]}\end{array}$ & Slope & $\begin{array}{c}\text { Slope } \\
\text { function } \\
(\mathrm{S}) \\
\end{array}$ & $\begin{array}{c}\text { Resistance } \\
\text { Ratio } \\
\text { (RR) LC } \mathbf{L C}_{\mathbf{5 0}}\end{array}$ \\
\hline \multirow{2}{*}{ Wild } & 24 & $\begin{array}{c}0.569 \\
(0.312-1.036)\end{array}$ & $\begin{array}{c}17.078 \\
(9.186-31.752)\end{array}$ & $\begin{array}{c}3000.335 \\
(765.98-11752.22)\end{array}$ & 0.5699 & 55.169 & \multirow{2}{*}{68.28} \\
\hline & 48 & $\begin{array}{c}0.027 \\
(0.012-0.059)\end{array}$ & $\begin{array}{c}0.993 \\
(0.590-1.673)\end{array}$ & $\begin{array}{c}244.019 \\
(80.883-736.186)\end{array}$ & 0.5356 & 71.574 & \\
\hline \multirow{2}{*}{ Lab. } & 24 & $\begin{array}{c}0.002 \\
(0.001-0.008)\end{array}$ & $\begin{array}{c}0.250 \\
(0.098-0.640)\end{array}$ & $\begin{array}{c}475.947 \\
(61.119-3706.280)\end{array}$ & 0.3859 & 350.695 & \multirow{2}{*}{84.41} \\
\hline & 48 & $\begin{array}{c}0.0001 \\
(0.0001-0.0002) \\
\end{array}$ & $\begin{array}{c}0.017 \\
(0.004-0.076) \\
\end{array}$ & $\begin{array}{c}71.789 \\
(9.826-524.508) \\
\end{array}$ & 0.3476 & 661.608 & \\
\hline
\end{tabular}

Table (8). Effect of different concentrations of Isomectin on the late $3^{\text {rd }}$ instar of wild strain of Culex pipiens larvae.

\begin{tabular}{ccc}
\hline $\begin{array}{c}\text { Concentration } \\
(\mathbf{m g} / \mathbf{L})\end{array}$ & \multicolumn{3}{c}{ Mortality (\%) } \\
\cline { 2 - 3 } & After 24 hr., & After 48 hr., \\
\hline $\mathbf{1 0 0}$ & $100 \mathrm{a}$ & $100 \mathrm{a}$ \\
$\mathbf{1 0}$ & $91 \mathrm{a}$ & $100 \mathrm{a}$ \\
$\mathbf{1}$ & $54 \mathrm{~b}$ & $92 \mathrm{a}$ \\
$\mathbf{0 . 1}$ & $24 \mathrm{c}$ & $74 \mathrm{~b}$ \\
$\mathbf{0 . 0 1}$ & $10 \mathrm{~d}$ & $28 \mathrm{c}$ \\
Control & $1 \mathrm{~d}$ & $7 \quad \mathrm{D}$ \\
\hline
\end{tabular}

Means followed with the same letters (column wise) are not significantly different (Tukeys HSD, $\mathrm{P} \leq 0.05$ ).

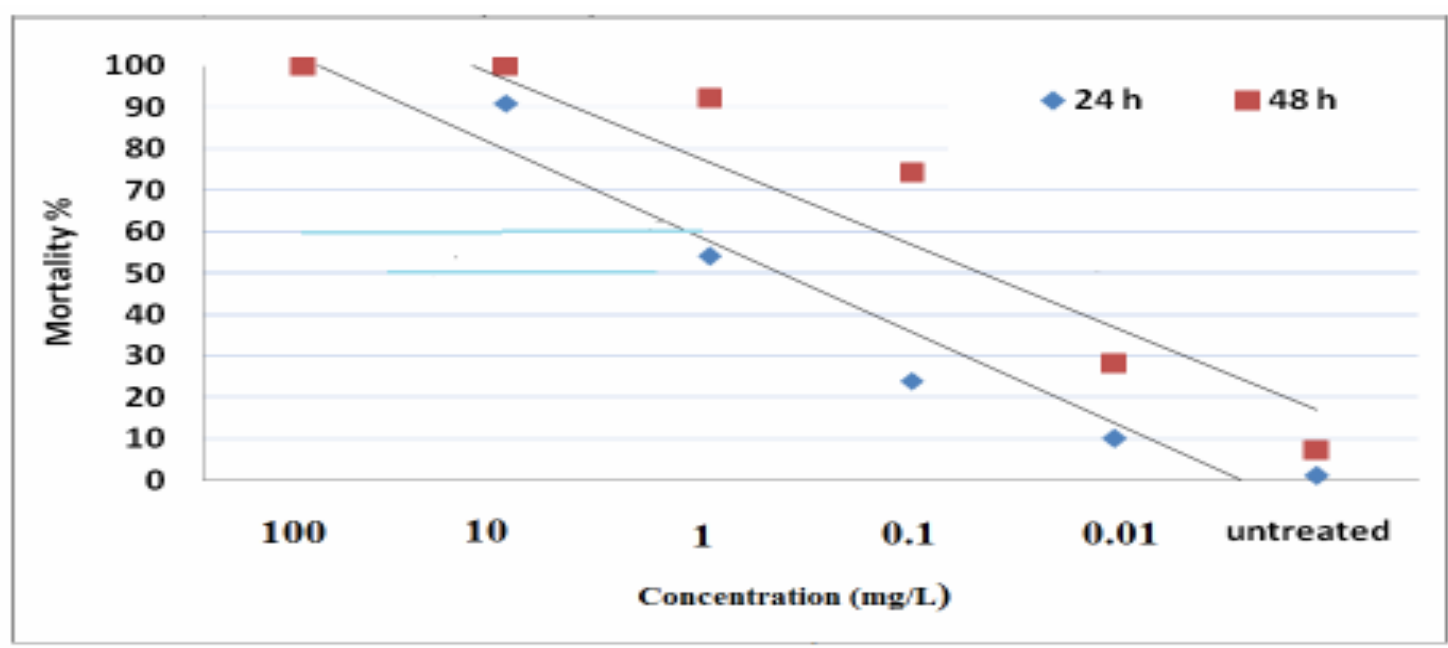

Fig. 5. Toxicity lines of Isomectin against the late $3^{\text {rd }}$ instar of wild strain of Culex pipiens larvae. 
Results obtained from Table (9) show the mortality percentage of the late $3^{\text {rd }}$ instar of lab. strain of Culex pipiens larvae after 24 and 48 hours of exposure to different concentrations of Isomectin insecticide.

Likewise the wild strain, the mortality percentage was increased gradually with increasing the Isomectin concentrations and the mortality percentage showed significant differences between concentrations and control $(\mathrm{F}=115.782 ; \mathrm{P} \leq 0.0000$ after $24 \mathrm{hr}$., of treatment and $\mathrm{F}=45.347 ; \mathrm{P} \leq 0.0000$ after $48 \mathrm{hr}$., of treatment). Moreover, results showed that mortality percentage increased with increasing the time of insecticide exposure for Culex pipiens larvae.

The toxicity lines in Fig. (6) reveale that the regression equation and regression of the mortality percentage after 24 and 48 hours of exposure $\left(y=-19.25 x+103.0 ; R^{2}=\right.$ 0.893 after $24 \mathrm{hr}$., of treatment and $\mathrm{y}=$ $18.22 \mathrm{x}+132.8 ; \mathrm{R}^{2}=0.859$ after $48 \mathrm{hr}$., of treatment. Results revealed that mortality percentage was concentration-dependent and time of exposure.

The value of $\mathrm{LC}_{20}, \mathrm{LC}_{50}$ and $\mathrm{LC}_{90}$ were tabulated in Table (10) with the corresponding slope, slope function and resistance ratio for Isomectin insecticide against the wild and lab strain of Culex pipiens larvae after 24 and 48 hours of exposure.

The results of larvae showed that Isomectin was moderate toxic to both of wild and lab strain of larvae than the high toxic Radiant and the low toxic Nimbecidine. The resistance ratio of the response of the late $3^{\text {rd }}$ instar of Culex pipiens larvae to the bio-insecticidal pressure of Isomectin was 2.06 and 16 .

Results showed relatively low level of resistance. The slope values proved that the homogeneity between lab and wild individuals. Results obtained from Tables (11 and 12) revealed that Radiant insecticide was more toxic among the tested insecticides followed by Isomectin and Nimbecidine for both the wild and lab strain of mosquitoes. Moreover, the toxicity index of the tested insecticides proved the high toxicity of Radiant than Isomectin and Nimbecidine.

\section{DISCUSSION}

The current study provides such information on the toxicity of these natural bio-insecticides against the late $3^{\text {rd }}$ instar larvae of Culex pipiens.

This study, carried out in the laboratory revealed that Radiant, Isomectin and Nimbecidine insecticides had good impact and powerful toxicity on Culex pipiens larvae particularly Radiant and Isomectin. In this study, Radiant and Isomectin had high impact and toxic effect than Nimbecidine after 24 and 48 hours of insecticide exposure.

These findings are in conformity with those reported by El-Kady et al. (2008) who mentioned that Spinosad and Isomectin had significant effects on the percentage of larval mortality of Culex pipiens. Walaa et al. (2015) reported that the highest larvicidal effect was recorded for Spinosad treatment followed by Temephos, Fenitrothion then Malathion.

Ali and Nayer (1985) mentioned that the highest larvicidal effect was recorded for Abamectin against Aedes aegypti and Culex quinquefasciatus. Alouani et al. (2009) proved that Azadirachtin had high larvicidal effect against Culex pipiens, similar results were obtained by Alkofahi et al. (1989).

In its Twenty five years of use, resistance to Spinosad has been limited in part because of its unique mode of action. Thus, no cross-resistance to Spinosad has been measured in mosquitoes that are resistant to pyrethroids or OPs (Darriet et al., 2005). 
SINAI Journal of Applied Sciences (ISSN: 2314-6079) Vol. (6) Is. (3), Dec. 2017

Table (9). Effect of different concentrations of Isomectin on the late instar of lab. strain of Culex pipiens larvae.

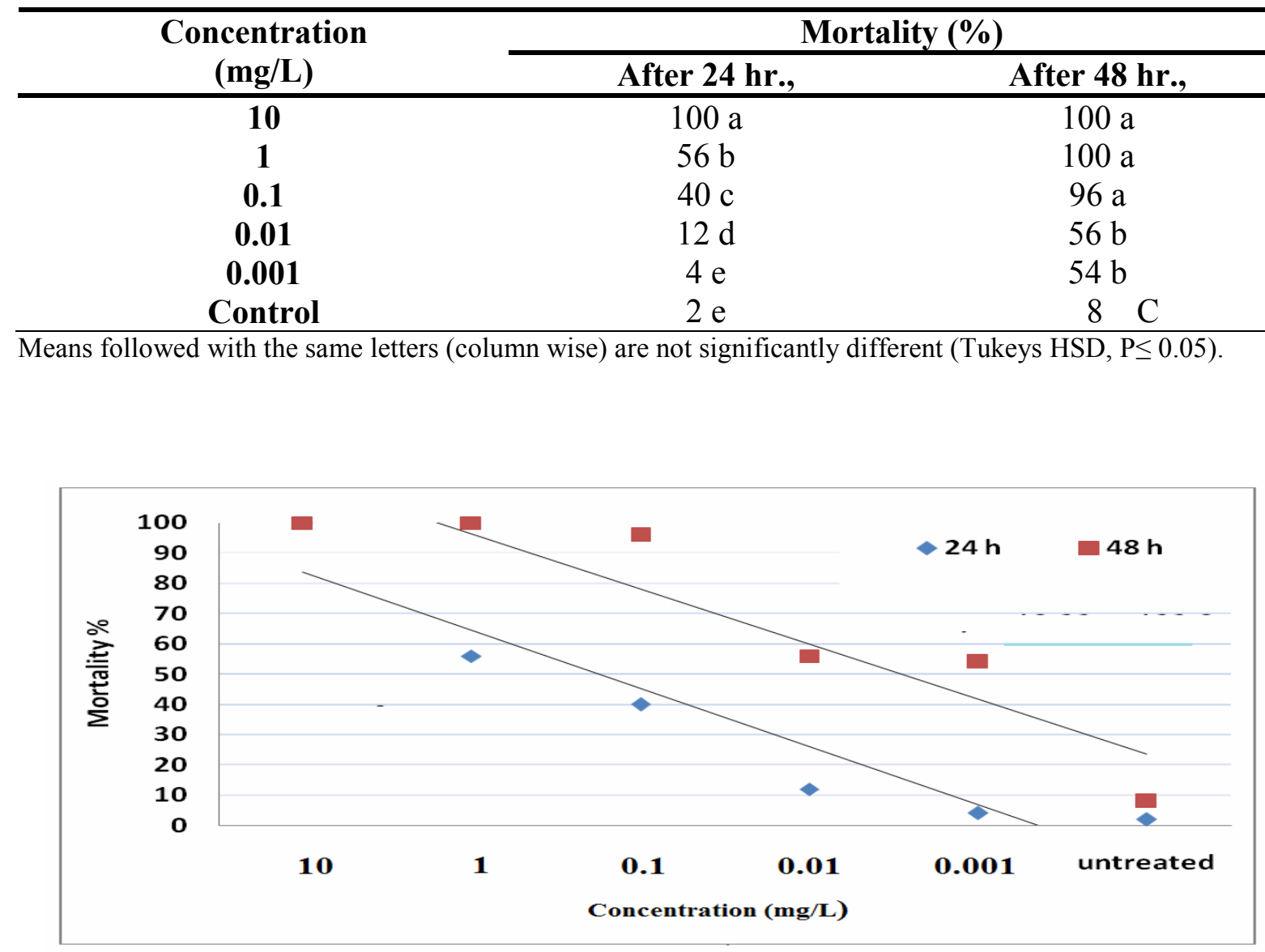

Fig. 6. Toxicity lines of Isomectin against the late $3^{\text {rd }}$ instar of lab strain of Culex pipiens larvae.

Table (10). Toxicity data of Isomectin on the late $3^{\text {rd }}$ instar of wild and laboratory strain of Culex pipiens larvae.

\begin{tabular}{|c|c|c|c|c|c|c|c|}
\hline $\begin{array}{l}\text { Mosquitc } \\
\text { strain }\end{array}$ & $\begin{array}{c}\text { Time of } \\
\text { exposure } \\
\text { (Hours) }\end{array}$ & $\begin{array}{c}\mathbf{L C}_{20}(\mathrm{mg} / \mathrm{l}) \\
{[95 \% \mathrm{CI}]}\end{array}$ & $\begin{array}{c}\mathrm{LC}_{50}(\mathrm{mg} / \mathrm{l}) \\
{[95 \% \mathrm{CI}]}\end{array}$ & $\begin{array}{c}\mathrm{LC}_{90}(\mathrm{mg} / \mathrm{l}) \\
{[95 \% \mathrm{CI}]}\end{array}$ & Slope & $\begin{array}{c}\text { Slope } \\
\text { function } \\
\text { (S) }\end{array}$ & $\begin{array}{l}\text { Resistance } \\
\text { ratio } \\
(\mathrm{RR}) \mathrm{L} \mathrm{LC}_{5}\end{array}$ \\
\hline \multirow{2}{*}{ Wild } & 24 & $\begin{array}{c}0.058 \\
(0.036-0.093)\end{array}$ & $\begin{array}{c}0.478 \\
(0.335-0.683)\end{array}$ & $\begin{array}{c}11.724 \\
(6.595-20.840)\end{array}$ & 0.8964 & 11.966 & \multirow{2}{*}{2.06} \\
\hline & 48 & $\begin{array}{c}0.005 \\
(0.003-0.009)\end{array}$ & $\begin{array}{c}0.032 \\
(0.022-0.047)\end{array}$ & $\begin{array}{c}0.514 \\
(0.303-0.870)\end{array}$ & 0.9973 & 8.622 & \\
\hline \multirow{2}{*}{ Lab. } & 24 & $\begin{array}{c}0.024 \\
(0.015-0.038)\end{array}$ & $\begin{array}{c}0.232 \\
(0.159-0.338)\end{array}$ & $\begin{array}{c}7.362 \\
(3.782-14.329)\end{array}$ & 0.8392 & 14.612 & \multirow{2}{*}{16} \\
\hline & 48 & $\begin{array}{c}0.0001 \\
(0.0001-0.0002)\end{array}$ & $\begin{array}{c}0.002 \\
(0.001-0.003)\end{array}$ & $\begin{array}{c}0.069 \\
(0.036-0.133)\end{array}$ & 0.7321 & 18.487 & \\
\hline
\end{tabular}

(Resistance ratio $(\mathrm{RR})=\mathrm{LC}_{50}$ of wild strain/ $\mathrm{LC}_{50}$ of lab. Strain. 
Table (11). Toxicity index of the tested insecticides against wild and lab strains after 24 hours of exposure.

\begin{tabular}{ccccc}
\hline \multirow{2}{*}{ Insecticide } & \multicolumn{2}{c}{ LC $_{\mathbf{5 0}}$} & \multicolumn{2}{c}{ Toxicity index } \\
\cline { 2 - 5 } & Wild strain & Lab strain & Wild strain & Lab strain \\
\hline Radiant & 0.006 & 0.0035 & 100 & 100 \\
Nimbecidine & 17.07 & 0.250 & 0.035 & 1.2 \\
Isomectin & 0.478 & 0.232 & 1.25 & 1.29 \\
\hline
\end{tabular}

Table (12). Toxicity index of the tested insecticides against wild and lab strain after 48 hours of exposure.

\begin{tabular}{ccccc}
\hline \multirow{2}{*}{ Insecticide } & \multicolumn{2}{c}{ LC $_{\mathbf{5 0}}$} & \multicolumn{2}{c}{ Toxicity index } \\
\cline { 2 - 5 } & Wild strain & Lab strain & Wild strain & Lab strain \\
\hline Radiant & 0.0005 & 0.0003 & 100 & 100 \\
Nimbecidine & 0.993 & 0.017 & 0.05 & 1.76 \\
Isomectin & 0.032 & 0.002 & 1.56 & 15 \\
\hline
\end{tabular}

\section{Conclusion}

The present work demonstrated that Spinosad, Isomectin and Nimbecidine proved to be effective and viable alternative to broad spectrum of insecticides for controlling mosquito larvae.

\section{REFERENCES}

Ali, A. and Nayar, J.K. (1985). Activity of an avermectin insecticide, Abamectin (MK-936), against mosquitoes and chironomid midges in the laboratory. J. Ame. Mosquito Control Association, 1(3): 384-386.

Alkofahi, A., Rupprecht, J.K., Anderson, J.E., Mclaughlin, J.L., Mikolajczak, K.L. and Scott, B.A. (1989). Search for new pesticides from higher plants. In:

Arnason, J.T., Philogene, BJR., Morand, P. (Eds.) Insecticides of Plant Origin. Ame. Chemical Soci., Washington, DC, pp. 25-43.
Alouani, A., Rehimi, N. and Soltani, N. (2009). Larvicidal activity of a neem tree extract (Azadirachtin) against mosquito larvae in the Republic of Algeria. Jordan J. Bio. Sci., 2(1): 15-22.

Athanassiou, C.G., Kavallieratos, N.G. and Chintzoglou, G.J. (2008). Effectiveness of spinosad dust against different European populations of the confused flour beetle, Tribolium confusum Jacquelin du Val. J. stored pro. Res., 44(1): 47-51.

Burg, R. W., Miller, B. M., Baker, E.E., Birnbaum, J., Currie, S.A., Hartman, R. and Tunac, J.B. (1979). Avermectins, new family of potent anthelmintic agents: producing organism and fermentation. Antimicrobial agents and Chemotherapy, 15(3): 361-367.

Butters, M.P., Kobylinski, K.C., Deus, K.M., Da Silva, I.M., Gray, M., Sylla, M. and Foy, B.D. (2012). Comparative evaluation of systemic drugs for their 
effects against Anopheles gambiae. Acta tropica, 121(1): 34-43.

Campbell, W.C. (2012). History of avermectin and ivermectin, with notes on the history of other macrocyclic lactone antiparasitic agents. Current pharmaceutical biotech., 13(6): 853-865.

Damaria, S.R., Sridhar, S., Raman, K. and Gopinathan, M.C. (2004). United States Patent No. 6,811,790. Washington, DC: United States Patent and Trademark Office. Storage stable pesticide formulations containing azadirachtin. E.I.D. Parry, India.

Darriet, F., Duchon, S. and Hougard, J.M. (2005). Spinosad: a new larvicide against insecticide-resistant mosquito larvae. J. Ame. Mosquito Cont. Association, 21(4): 495-496.

El- Kady, G.A.E.L., Kamel, N.H., Mosleh, Y.Y. and Bahght, I.M. (2008). Comparative toxicity of two bioinsecticides (Spinotoram and Vertemic) compared with methomyl against Culex pipiens and Anopheles multicolor. World J. Agri. Sci., 4(2): 198-205.

Hanafi, H.A., Fryauff, D. J., Saad, M.D., Soliman, A.K., Mohareb, E.W., Medhat, I., Zayed, A.B., Szumlas, D.E. and Earhart, K.C. (2011). Virus isolations and high population density implicate Culex antennatus (Becker) (Diptera: Culicidae) as a vector of Rift Valley Fever virus during an outbreak in the Nile Delta of Egypt. Acta tropica, 119(2): 119-124.

Karunamoorthi, K. and Sabesan, S. (2013). Insecticide resistance in insect vectors of disease with special reference to mosquitoes: a potential threat to global public health. Health Scope, 2(1): 4-18.

Mahmoud, M.F. and Shoeib, M.A. (2008). Sterilant and oviposition deterrent activity of neem formulation on
Peach fruit fly Bactrocera Zonata (Saunders) (Diptera: Tephritidae). J. Biopesticides, 1(2): 177-181.

Pampiglione, S., Majori, G., Petrangeli, G. and Romi, R. (1985). Avermectins, MK-933 and MK-936, for mosquito control. Transactions of the Royal Society of Tropical Medicine and Hygiene, 79(6): 797-799.

Pitterna, T., Cassayre, J., Hüter, O. F., Jung, P. M., Maienfisch, P., Kessabi, F. M., Maienfisch, P., Kessabi, F. M., Quaranta, L. and Tobler, H. (2009). New ventures in the chemistry of avermectins. Bioorganic and medicinal chemistry, 17(12): 4085-4095.

Salgado, V.L. (1997). The modes of action of Spinosad and other insect control products. Down to earth, 52(1): 35-43.

Salgado, V.L. (1998). Studies on the mode of action of Spinosad: insect symptoms and physiological correlates. Pesticide Bioch. and Physiolo., 60(2): 91-102.

SAS Institute (2004). Version 9.1 SAS/STAT Users Guide. Vol. 1 and 2. Cary, N C., USA

Saxena, R.C. (1983). Naturally occurring pesticides and their potential. Chemistry and world food supplies. The New Frontiers, McMaster University, Pergamon Press, Hamilton, Ontário, Canadá, 143-162.

Schoofs, G.M. and Willhite, C.C. (1984). A probit analysis program for the personal computer. J. Appl. Toxicol., 4(3): 141-144.

Shoeib, M.A., Mahmoud, M. F., Loutfy, N., Tawfic, M. A., and Barta, M. (2010). Effect of botanical insecticide Nimbecidine ${ }^{\circledR}$ on food consumption and egg hatchability of the terrestrial snail Monacha obstructa. J. pest sci., 83(1): 27-32. 
Southgate, B.A. (1979). Bancroftian filariasis in Egypt. Trop. Dis. Bull., 76: 1045-1063.

Ventura, M.U. and Ito, M. (2000). Antifeedant activity of Melia azedarach (L.) extracts to Diabrotica speciosa (Genn.) (Coleoptera: Chrysomelidae) beetles. Brazilian Archives of Biology and Technolo., 43(2): 215-219.

Walaa A. M., Abdelbaset B. Z., Azza A. M., Hanaa I. M. and Shaimaa $H$. (2015). Spinosad as an Alternative
Larvicide for Mosquito Culex pipiens Control. Current Sci. Int., 4(4): 646-657.

Zayed, A. B. B., Szumlas, D.E., Hanafi, H. A., Fryauff, D. J., Mostafa, A. A., Allam, K.M. and Brogdon, W.G. (2006). Use of bioassay and microplate assay to detect and measure insecticide resistance in field populations of Culex pipiens from filariasis endemic areas of Egypt. J. Ame., Mosquito Cont. Association, 22(3): 473-482.

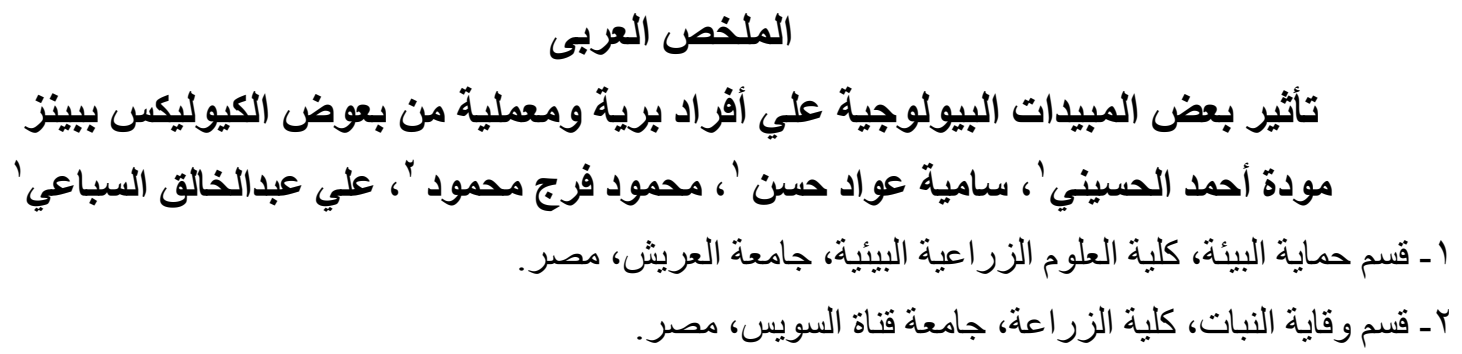

تعتبر البعوضة المنزلية (الكيوليكس بيينز) هي الحشرة الطبية الأكثر أهمية في أنحاء كثيرة في العالم، المبيدات

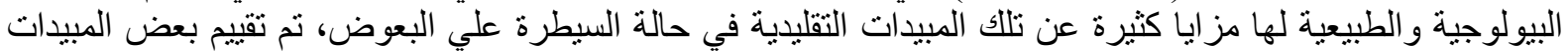

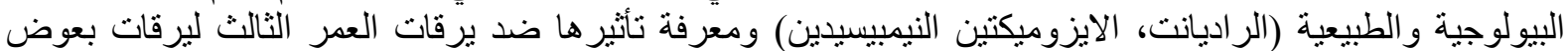

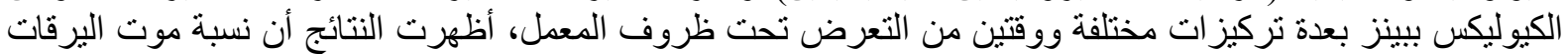

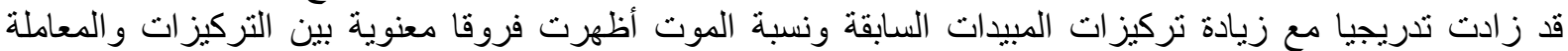

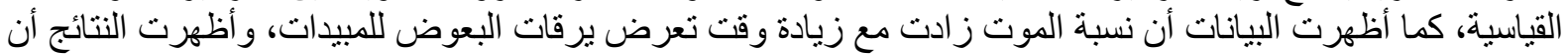

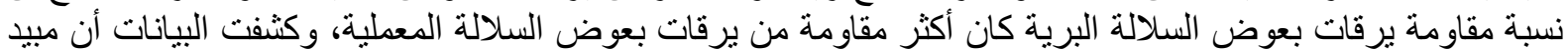

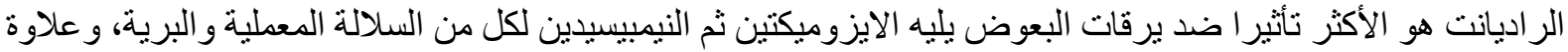

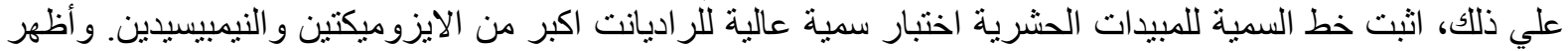
خط السمية للر اديانت للجر عة المميتة للنصف فعالية متفوقة ( · ( \%) تليها الايزو ميكتين ثم النيمبيسيدين. الكلمات الإسترشادية: الكيوليكس ببينز، المبيدات الحشرية، تأثير ، مقاومة.

أستاذ الحشر ات الاقتصادية، كلية الزر اعة، جامعة قناة السويس، مصر.

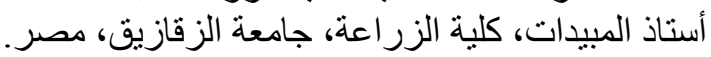

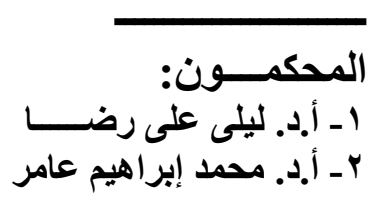

